\title{
Primordial Germ Cell Profile Incubated for 24 Hours in the Phosphate Buffer Saline [-] Solution
}

\author{
Kostaman T, Sopiyana S \\ Indonesian Research Institute for Animal Production, \\ Jl. Veteran III Banjarwaru, PO Box 221, Bogor 16002, Indonesia \\ E-mail: tatankostaman@gmail.com
}

(received 03-07-2017; revised 25-08-2017; accepted 04-09-2017)

\begin{abstract}
ABSTRAK
Kostaman T, Sopiyana S. 2017. Gambaran primordial germ cell yang diinkubasi selama 24 jam dalam larutan phosphat bufer saline [-]. JITV 22(3): 144-150. DOI: http://dx.doi.org/10.14334/jitv.v22i3.1802

Perkembangan gonad adalah sebuah rangkaian proses terdiri dari tiga peristiwa besar, yaitu migrasi PGC, penentuan jenis kelamin, dan diferensiasi gonad. Penelitian ini bertujuan untuk melihat perkembangan PGC yang diisolasi dari gonad embrio, diinkubasi selama 7 hari dan kemudian diinkubasi dalam larutan Phosphat Bufer Saline (PBS) [-]. Gonad yang sedang berkembang dapat di isolasi dari embrio ayam umur 7 hari dan dapat di inkubasi pada temperatur $37,8^{\circ} \mathrm{C}$ dalam larutan PBS [-], yaitu tanpa $\mathrm{Ca} 2+$ dan $\mathrm{Mg} 2+$. Pelepasan PGC dari gonad diamati dalam waktu 1, 8, 16, dan 24 jam setelah gonad embrio dimasukkan ke dalam larutan PBS [-]. Hasil penelitian menunjukkan bahwa PGC dapat lepas dari jaringan gonad dan layak untuk dikoleksi dengan cara memasukkan gonad yang sedang berkembang ke dalam larutan PBS [-]. Jumlah PGC dan persentase survival rate tertinggi diperoleh setelah gonad diinkubasi selama 1 jam, namun tidak berbeda dengan 8 jam $(P>0,05)$, sedangkan dengan 16 dan 24 jam setelah inkubasi berbeda nyata $(\mathrm{P}<0,05)$. Sebaliknya untuk persentase tingkat kemurnian yang tertinggi adalah yang diinkubasi selama 8 jam, akan tetapi tidak menunjukkan perbedaan yang nyata dengan 1 dan 16 jam $(\mathrm{P}>0,05)$. Persentase tingkat kemurnian berbeda nyata setelah gonad diinkubasi selama 24 jam $(\mathrm{P}<0,05)$. Dapat disimpulkan bahwa waktu inkubasi yang paling tepat untuk mendapatkan PGC dari jaringan gonad embrio ayam KUB adalah pada waktu tidak lebih dari 8 jam.
\end{abstract}

Kata Kunci: Gonad, PGC, Ayam Lokal

\begin{abstract}
Kostaman T, Sopiyana S. 2017. Primordial germ cells profiles incubated for 24 hours in phosphate buffer saline [-] solution. JITV 22(3): 144-150. DOI: http://dx.doi.org/10.14334/jitv.v22i3.1802

Gonadal development is a sequential process that can be divided into three major events: the PGCs migration, sex determination and gonadal differentiation. This study was aimed to see the development of PGCs isolated from the gonads of embryos after being incubated for 7 days and then was incubated using a solution of Phosphate Buffer Saline (PBS) [-]. The developing gonad can be isolated from 7 days old chick and can be incubated at a temperature of $37.8^{\circ} \mathrm{C}$ in a solution of PBS [-]: without $\mathrm{Ca} 2+$ and $\mathrm{Mg} 2+$. The release of gonadal PGC was observed within 1, 8, 16, and 24 hours after the embryonic gonad was placed in a PBS solution [-]. The results showed that PGCs can be separated from gonadal tissues and can be collected by entering the developing gonad to the PBS [-] solution. The highest percentage of PGCs and survival rate was obtained after gonad was incubated for 1 hour and was not different with 8 hours $(\mathrm{P}>0.05)$. Those result was significantly different $(\mathrm{P}<0.05)$ with the 16 and 24 hours incubation. The highest purity rate percentage was in the 8 hours incubation, but did not show a significant difference $(\mathrm{P}>0.05)$ with the 1 and 16 hours incubation. The percentage of the purity differed $(\mathrm{P}<0.05)$ after the 24 hours incubation. It can be concluded that the most appropriate incubation time to obtain PGCs from the KUB chicken embryonic gonad is no more than 8 hours.
\end{abstract}

Key Words: Gonad, PGCs, Native Chicken

\section{INTRODUCTION}

Primordial germ cell (PGC) are the precursors of the progenitors of the oocytes and spermatocytes, or according to D'Costa et al. (2001), PGC are the precursors of mature ovum and spermatozoa of the mature poultry and an intergenerational genetic linkage. Germ cells play a very important role in the species identification as they transmit genetic information to the next generation. In many animal species, including birds, germ cells emerge from a small population of cells known as PGC (Bednarczyk 2014).

Chicken PGCs were collected from the germinal crescent (Naito et al. 2001), the embryonic blood vessel (Naito et al. 1994) and from the embryonic gonads (Park et al. 2003). Although no phenotypic changes between the different sources of PGcs were observed, and the expression patterns of specific markers were 
identical (Park \& Han 2012), however the advantage of using gonadal PGcs compared with another sources of these cells is, that a greater number of PGcs can be retrieved from one embryo. (Bednarczyk 2014)

Characterization and detail description of the differentiation of the germinal cell gen will result in better understanding of fertility, germ cell tumor and contraception method (Kakegawa et al. 2008).

A unique character of poultry PGC during the initial development provides a chance to manipulate the poultry germplasm. Two purpose of PGC use widely reported is for the conservation of genetic resources especially the endanger poultry germplasm (Glover \& McGrew 2012) and the production of transgenic poultry (Nakamura et al. 2013).

The primordial germ on poultry has a significant potential to be used in cell-based studies since it can be collected from the blastoderm, embryo blood and embryo gonad (Chojnacka-Puchta et al. 2012) Although there is no phenotypic change between the various PGC sources observed and the expression pattern of the certain marker, most PGC can be collected only from one embryo which is an advantage of the gonad PGC (Park \& Han 2012). Considering the difficulty of the collection process from the tissue, the isolation and culture of the chicken PGC from embryo gonad may provide many sources for the chicken genetic manipulation (Shiue et al. 2009).

Isolation method of the gPGC using PhosphateBuffered Saline (PBS) [-] solution is a simple method developed for chicken PGC isolation derived from the gonad tissue. The advantage of the gPGC isolate using the PBS [-] is easy to be collected in the short time and does not require expensive equipment (Nakajima et al. 2011). PBS is a media which is very useful and convenient for various animal cell cultures. Besides, the PBS is rich in nutrient (dos Santos et al. 2002). PBS is available commercially in the different formulation: PBS with calcium and magnesium (PBS[+]) and without calcium and magnesium (PBS[-]). Therefore, it was conducted a study to isolate PGC derived from gonad tissue with high purity by incubating the embryo gonad in the PBS [-] for 24 hours

\section{MATERIALS AND METHODS}

\section{Location}

This study was conducted at the Laboratory of NonRuminant Reproduction, Indonesian Research Institute for Animal Production (IRIAP), Ciawi-Bogor.

\section{Fertile egg preparation}

The eggs used in this study was 60 fertile eggs of Kampung Unggul Balitbangtan (KUB) chicken from the IRIAP, Ciawi-Bogor. Those eggs were cleaned using cotton moistened with $70 \%$ alcohol, then were incubated in a portable incubator (P-008B Biotype; Showa Furanki, Saitama, Japan) with $37.8^{\circ} \mathrm{C}$ of temperature for 7 days.

\section{Procedure of gonad collection}

The 7 days old eggs were taken from the incubator and placed in an egg tray. One by one egg was cracked using tweezers on the plunt part to create a small hole. The small hole was cracked more slowly to create a bigger hole to see the embryo (Figure 1).

The embryo was carefully separated and put into a petri dish (90x15mm, LBS60001PT, BIOLAB) filled with PBS [-] solution. This process was repeated for all embryo. One by one embryo was taken and placed into a charcoal plate filled with the PBS [-] where its abdomen part was upward. The head and legs were pinned using a pin to lock the embryo during the gonad collection (Figure 2).

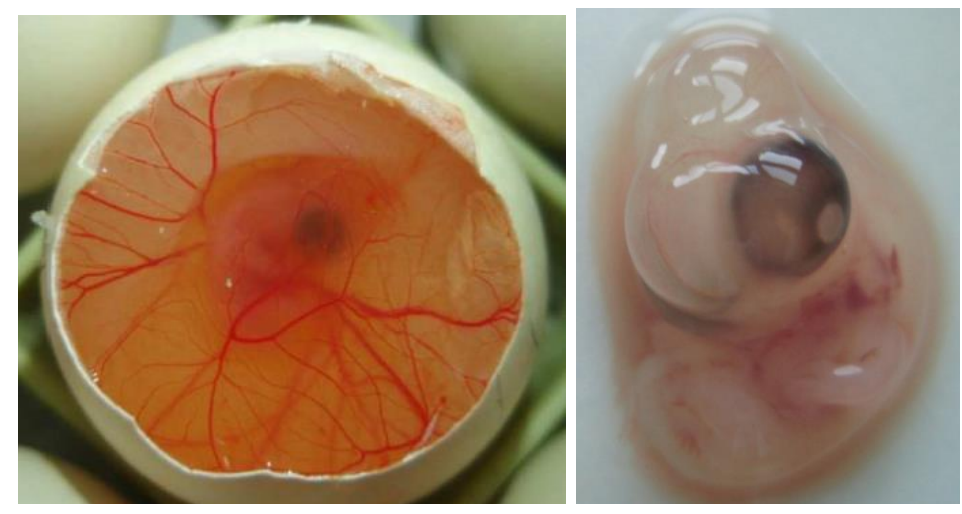

Figure 1. The normal development of KUB chicken embryo incubated for 7 days. 


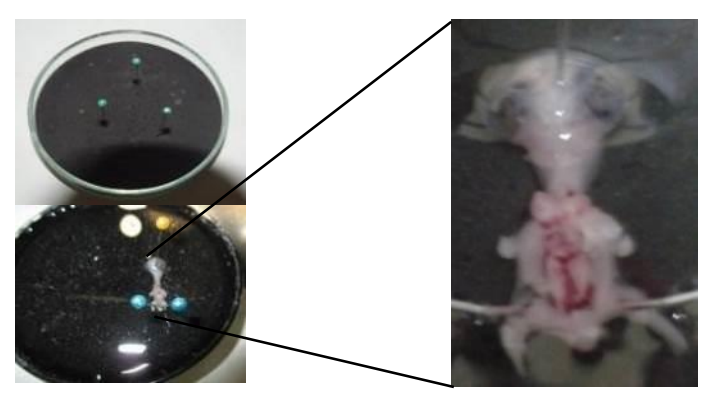

Figure 2. Embryo of KUB chicken incubated for 7 days placed on the charcoal plate.

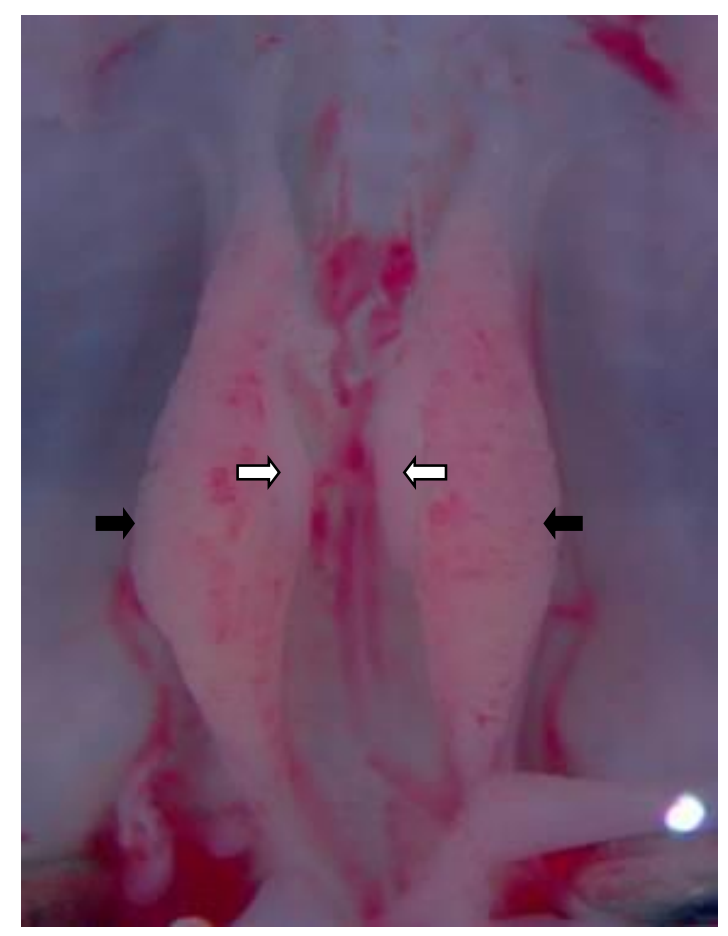

Figure 3. Gonad position (the white arrows) of KUB embryo incubated for 7 days observed under Microsoft with 400x magnification attaching to the right and left mesonephros (the black arrows).

The abdomen and the innards were removed using tweezer carefully to see the mesonephros. The gonad is attached to the left and right mesonephros (Figure 3). Gonad was taken carefully using a tweezer, verify that the gonad can be taken with no cut off and there no other part included.

\section{Isolation and Collection of Gonadal Primordial Germ Cell}

After the 7 days incubation, both left and right gonads successfully isolated were placed in the $1.5 \mathrm{ml}$ Eppendorf tube filled by $500 \mu \mathrm{l}$ PBS [-] and then incubated for $1,8,16$ and 24 hours in the $\mathrm{CO} 2$ incubator (Thermoline) at $37.80 \mathrm{C}$, then, the purity of PGC was performed following Nakajima et al. (2011).

\section{Variables}

Variables visually observed was morphological characteristic which was identic with the PGC circulation as a huge round cell with large nucleus that was observed under contrast phase Microsoft (Olympus CKX41, Japan), the number of PGC, survival rate (measured using trypan blue staining of Nakajima et al. 2011) and level of purity (defined as ratio of PGC amount released and total cell amount removed that expressed in percentage)

\section{Statistical Analysis}

Data of morphological characteristic were analyzed descriptively. Average PGC amount, survival rate, and purity level were analyzed in the ANOVA. It was 
continued by Duncan test when there was a difference using SPSS Ver 10 program.

\section{RESULTS AND DISCUSSION}

The basic principle of PGC isolation using PBS [-] solution is storing the gonad has been removed from the mesonephros and then incubated in the PBS [-]. The isolated PGC (Figure 4) under the contrast phase Microsoft showed a unique characteristic of PGC and almost similar with circulation-PGC (cPGC) which having a large nucleus. Also, it showed several membrane microphilies that is important for in vivo migration (Raucci et al. 2015). Microscopic observation with larger magnification showed a large nucleus with a diameter of about $9 \mu \mathrm{m}$, which was eccentric. Several cPGC had pseudopodia and irregular shape showing the character of this cells is in the development stage (Kuwana \& Rogulska 1999).

Gonad embryo within 7 days of incubation chicken contained a little (if there was any) somatic cells and rarely or no connective tissue between PGC (Nakajima \& Tajima 2013). This is common that the gonad of somatic cells promotes the maturation and differentiation of germinal cells in the gonad (Johnson 2000; Kirby \& Froman 2000). Although the mechanisms underlying PGC release from gonadal development in PBS [-] are not understood, the fast and simple method described in this study will be very convenient for the production of germline chimera.
The releasing or migrating the PGC from gonad tissue can be performed by incubating the gonad in the PBS [-] solution (Figure 5). The PBS [-] solution played the main role to create an ideal micro environment for PGC interact, maintaining the pluripotency or differentiating into functional germinal. This structure showed that the current incubation condition was able to maintain the appropriate physiology of cell (Raucci et al. 2015). The other reason for the use of PBS [-] is because in the PGC release from gonadal tissue does not need a help from cation (Sopiyana et al. 2017).

Temporal change in the amount, survival rate and purity of the PGC isolated from gonad embryo incubated in the PBS [-] solution for 24 hours showed in Table 1. The increase of PGC amount which was not continuing collected after 16 and 24 hours incubation was compared to the 1 and 8 hours of incubation. This can be caused by the release of somatic cell continue to increase along with longer incubation time. A similar result was also reported by Nakajima et. al. (2014).

Average survival rate percentage of PGC was more than $80 \%$ at the first 8 hours of gonad incubation. It then decreased to $65 \%$ on the 24 hours incubation. This significant decrease in the survival rate of PGC after 8 hours of incubation can be correlated to the depletion of essential nutrients to maintain cell metabolism of PGC. This may because increased cellular metabolism has accelerated the consumption of nutrient media and beyond the PBS buffer power. Consequently, it results in longer incubation time which dos Santos et al. (2002)

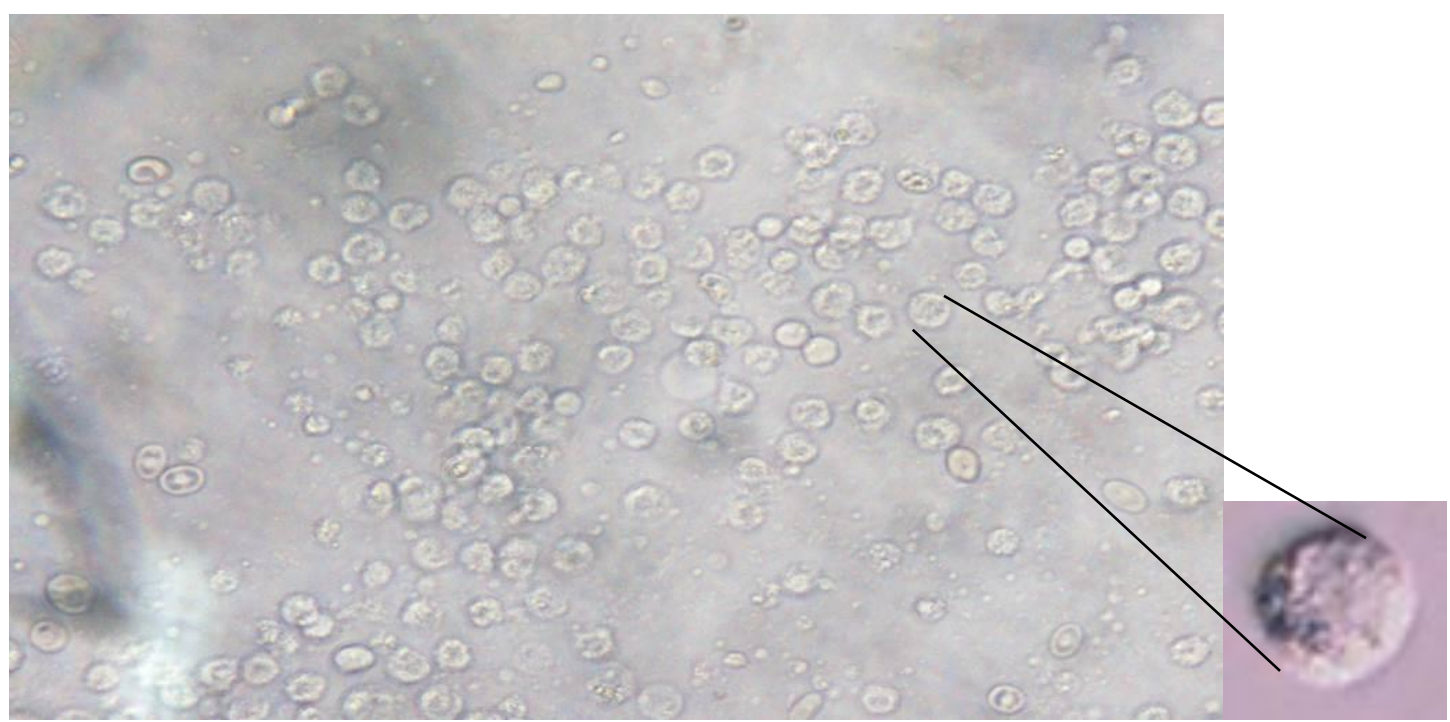

Figure 4. Primordial germ cell isolated from 7 days old gonad with 400x of magnification. 


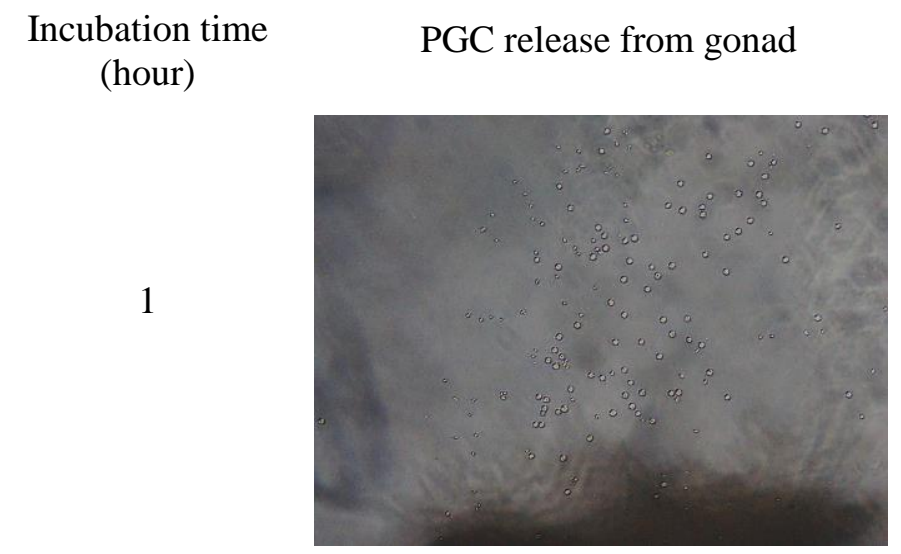

PGC after isolation
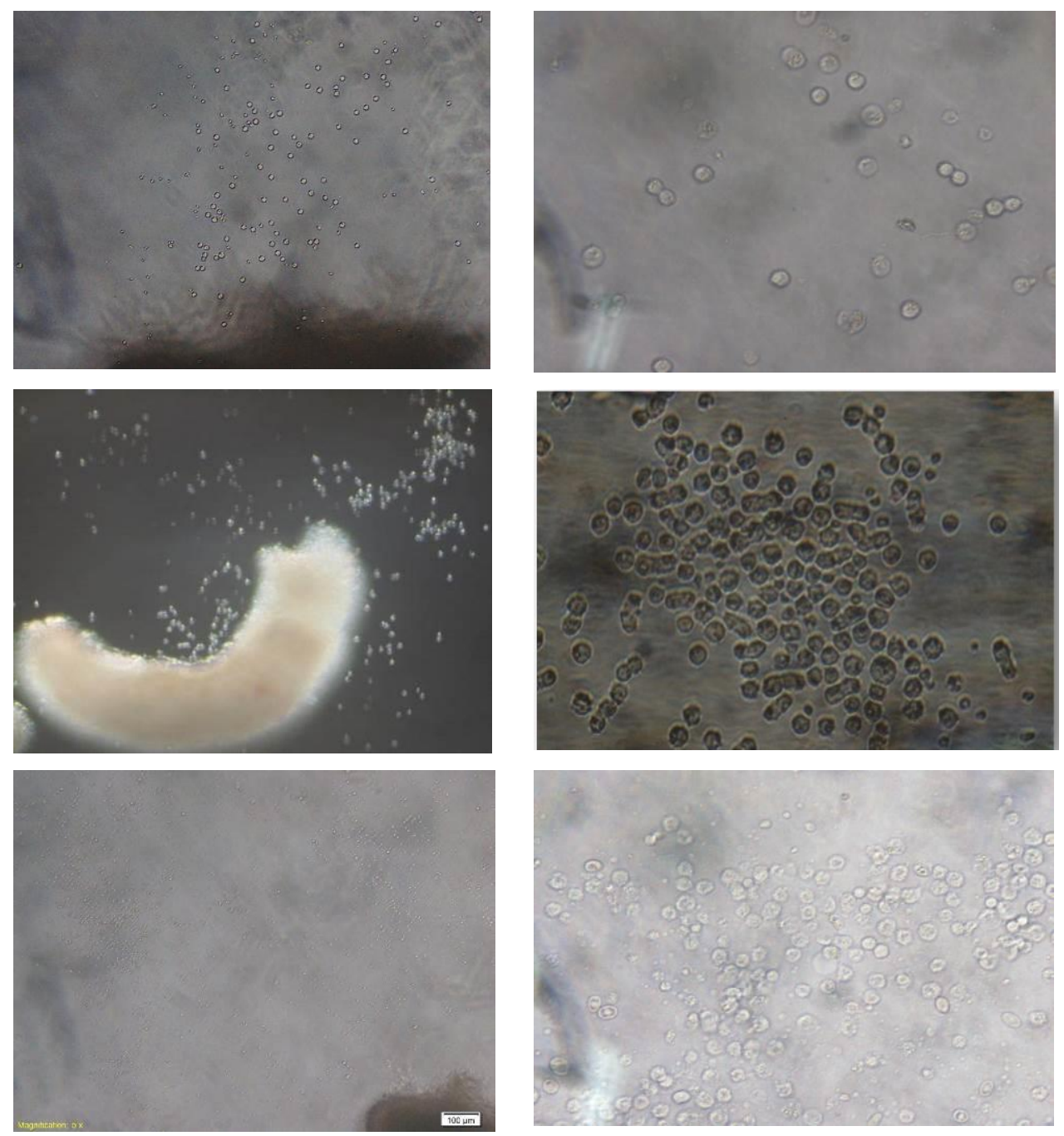

16
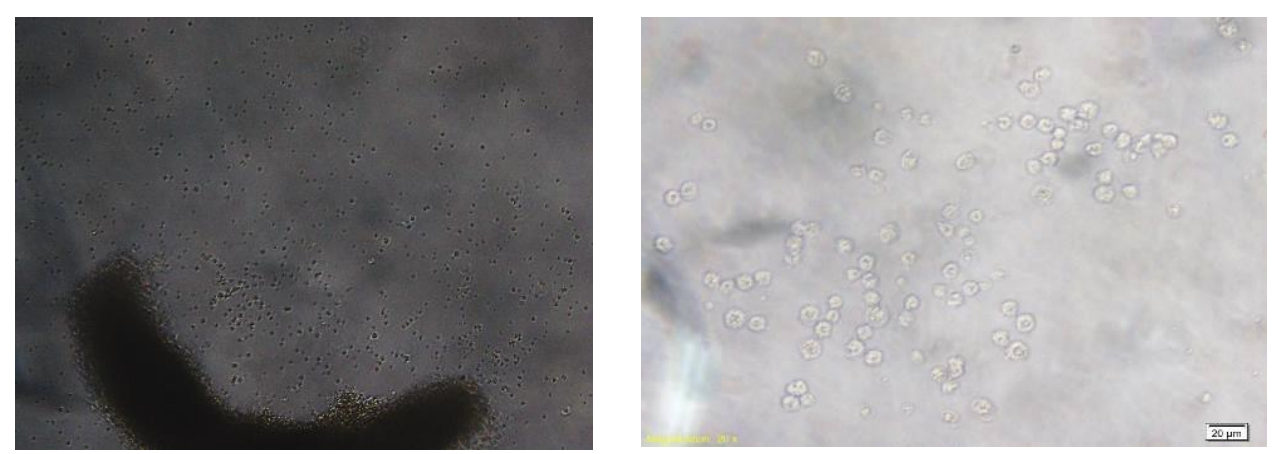

Figure 3. The average score of udder parenchymal (PAR) and mammary fat pads (MFP) of each quarter of buffalo calve udder. Score: $<1=$ very small PAR size/thin MFP, $1-<2=$ small PAR/medium MFP, $\geq 2=$ medium PAR/thick MFP. 
Kostaman T, Sopiyana S. Primordial germ cells profiles incubated for 24 hours in phosphate buffer saline [-] solution

Table 1. The Amount, survival rate and purity level of primordial germ cell (pgc) isolated from kub chicken embryos

\begin{tabular}{lcccc}
\hline \hline \multirow{2}{*}{ Variable } & \multicolumn{4}{c}{ Incubation Time (hour) } \\
\cline { 2 - 4 } & 1 & 8 & 16 & 24 \\
\hline gPGC amount (cell/embryo) & $151.47^{\mathrm{a}} \pm 16.12$ & $140.25^{\mathrm{a}} \pm 7.77$ & $122.40^{\mathrm{b}} \pm 5.75$ & $130.60^{\mathrm{b}} \pm 3.65$ \\
Survival rate (\%) & $90^{\mathrm{a}}$ & $82^{\mathrm{a}}$ & $70^{\mathrm{b}}$ & $65^{\mathrm{b}}$ \\
Purity level (\%) & $48^{\mathrm{a}}$ & $50^{\mathrm{a}}$ & $45^{\mathrm{a}}$ & $40^{\mathrm{b}}$ \\
\hline
\end{tabular}

Description: different superscript on the same rows shows a significant difference $(\mathrm{p}<0.05)$

described that the composition of media is a crucial factor to survive.

As well as the percentage of PGC purity level that decreased after 8 hours incubation. This may be caused by spontaneous dissociation of gonad was accelerated after 8 hours of incubation in the PBS [-] (Nakajima et al. 2014). Therefore, spontaneous PGC release into the PBS [-] solution from gonad embryo observed in this study may have been affected by the existence of protein adhesion cell such as cadherin and integrin controlled by the concentration of $\mathrm{Ca} 2+$ and $\mathrm{Mg} 2+$ (Gumbiner 2005; Lien et al. 2006).

The same result was also reported by Nakajima et al. (2011) on White Leghorn (WL) and Rhode Island Red (RIR) that showed longer incubation of gonad, the more decrease in survival rate and purity percentage of PGC. This decrease may also be correlated to the incubation time of the cell in the $\mathrm{CO} 2$ room. Storing cell more than 8 hours without media or calcium and magnesium compound may have contributed to high PGC mortality. It then Li et al. (2005) proved that more decrease in PGC amount when incubation caused by the cessation of aggregation factor by PGC, so that the PGC was back into phenotype derived from blood.

Currently, the fastest method for isolating PGC from gonad embryo of chicken is PBS [-] solution. This method provides a possibility to collect the most PGC amount purified and feasible to be transferred in a short time (Nakamura et al. 2013). It also has been proved that cells isolated from gonad and injected into $\mathrm{X}$ and 17 stage-embryo also experienced normal development and had normal gamete (Mozdziak et al. 2006).

It was expected from this study that isolation method of gPGC can be used in reproduction management system forming of specific-species for the success of Indonesian native chicken genetic resource. Also, it was expected that this new technology can help in reducing the maintenance cost and protecting the bird from an unexpected incident such as the highly pathogenic avian influenza or tsunami.

\section{CONCLUSION}

The most appropriate incubation time to obtain PCG isolated from KUB chicken embryo was from 1-8 hours. The Viability of PCG until 8 hours of incubation showed high PGC amount, the percentage of survival rate and purity compared to the 16 and 24 hours of incubation. To obtain the high PGC amount, survival rate and purity level, $\mathrm{Ca} 2+$ and $\mathrm{Mg} 2+$ should be added after 8 hours incubation.

\section{ACKNOWLEDGEMENT}

Authors wish to thank Prof. Dr. Argono R. Setioko for the advises, Tati Kurniasih and Agus Suhendri for the technical support in this study.

\section{REFERENCES}

Bednarczyk M. 2014. Avian Primordial Germ Cells and their Application. The 2nd International Scientific Conference "Animal Biotechnology". Slovak J Anim Sci. 47:185-187.

Chojnacka-Puchta L, Kasperczyk K, Plucienniczak G, Sawicka D, Bednarczyk. 2012. Primordial germ cells (PGCs) as a tool for creating transgenic chickens. Polish J Vet Sci. 15:181-188.

D'Costa S, Pardue SL, Petitte JN. 2001. Comparative development of avian primordial germ cells and production of germ line chimeras. Avian Poult Biol Rev. 12:151-168.

dos Santos RR, Silva JRV, Costa SHF, Rodrigues APR, Lobo RNB, de Figueiredo JR. 2002. Effect of $0.9 \%$ saline solution and phosphate buffer saline at different temperatures and incubation times on the morphology of goat preantral follicles. Braz J Vet Res Anim Sci. 39:254-259.

Glover JD, McGrew MJ. 2012. Primordial germ cell technologies for avian germplasm cryopreservation and investigating germ cell development. J Poult Sci. 49:155-162. 
Gumbiner BM. 2005. Regulation of cadherin-mediated adhesion in morphogenesis. Nat Rev Mol Cell Biol. 6:622-634.

Johnson AL. 2000. Reproduction in the female. In: Whittow GC, editors. Sturkie's avian physiology. 5th ed. London (UK): Academic Press. p. 569-596.

Kakegawa R, Teramura T, Takehara T, Anzai M, Mitani T, Matsumoto K, Saeki K, Sagawa N, Fukuda K, Hosoi Y. 2008. Isolation and culture of rabbit primordial germ cells. J Reprod Dev. 54:352-357.

Kirby JD, Froman DP. 2000. Reproduction in the female. In Whittow GC, editor. Sturkie's avian physiology. 5th ed. London (UK): Academic Press. p. 597-616.

Kuwana T, Rogulska T. 1999. Migratory mechanisms of chick primordial germ cells toward gonadal anlage. Cell Mol Biol. 45:725-736.

Li BC, Chen GH, Qin J, Wu XS, Wu SL, Cai ZT. 2005. Suitable stages for isolation and culture PGCs from chicken embryos. Int J Poult Sci. 4:885-890.

Lien WH, Klezovitch O, Vasioukhin V. 2006. Cadherincatenin proteins in vertebrate development. Curr Opinion Cell Biol. 18:499-506.

Mozdziak PE, Wysocki R, Angerman-Stewart J, Pardue SL, Petitte JN. 2006. Production of chick germline chimeras from fluorescence activated cell-sorted gonocytes. Poult Sci. 85:1764-1768.

Naito M, Sano A, Matsubara Y, Harumi T, Tagami T, Sakurai M, Kuwana T. 2001. Localization of primordial germ cells or their precursors in stage $\mathrm{X}$ blastoderm of chickens and their ability to differentiate into functional gametes in opposite-sex recipient gonads. Reproduction. 121:547-552.

Naito M, Tajima A, Yasuda Y, Kuwana T. 1994. Production of germline chimeric chickens, with high transmission rate of donor-derived gametes, produced by transfer of primordial germ cells. Mol Reprod Develop. 39:153162.

Nakajima Y, Asano A, Shikawa N, Tajima A. 2014. Factors involved in spontaneous discharge of gonadal germ gells from developing gonad of 7-day-old chick embryos. J Poult Sci. 51:416-423.

Nakajima Y, Minematsu T, Naito M, Tajima A. 2011. A new method for isolating viable gonadal germ cells from 7day old chick embryos. J Poult Sci. 48:106-111.

Nakajima Y, Tajima A. 2013. Development of a novel method for isolating gonadal germ cells from early chick embryos. J Dev Sustainable Agric. 8:75-78.

Nakamura Y, Tasai M, Takeda K, Nirasawa K, Tagami T. 2013. Production of functional gametes from cryopreserved primordial germ cells of the Japanese quail. J Rep Dev. 59:580-587.

Park TS, Han JY. 2012. Piggybac transposition into primordial germ cells is an efficient tool for transgenesis in chickens. Proc Natl Acad Sci. USA 109: 9337-9341.

Park TS, Hong YH, Kwon SC et al. 2003. Birth of germline chimeras by transfer of chicken embryonic germ (EG) cells into recipient embryos. Mol Reprod Dev. 65:389395.

Raucci F, Fuet A, Pain B. 2015. In vitro generation and characterization of chicken long-term germ cells from different embryonic origins. Theriogenology. 84:732742 .

Shiue YL, Tailiu JJ, Liou JF, Lu HT, Tai C, Shiau JW, Chen LR. 2009. Establishment of the long-term in vitro culture system for chicken primordial germ cells. Reprod Dom Anim. 44:55-61.

Sopiyana S, Supriatna I, Setiadi MA, Fahrudin M. 2017. Efisiensi isolasi primordial germ cell (PGC) dari sistem sirkulasi dan gonad serta produksi germline chimera pada ayam KUB (Disertation). [Bogor (Indones)]: Institut Pertanian Bogor. 